\title{
Influences of Extreme Upwelling on a Coastal Retention Zone
}

\author{
Julio B. J. Harvey ${ }^{1 *}$, John P. Ryan ${ }^{2}$ and Yanwu Zhang ${ }^{2}$ \\ 'Division of Physical and Biological Sciences, University of California, Santa Cruz, Santa Cruz, CA, United States, ${ }^{2}$ Monterey \\ Bay Aquarium Research Institute, Moss Landing, CA, United States
}

\section{OPEN ACCESS}

Edited by:

Alejandro Jose Souza,

Center for Research and Advanced

Studies - Mérida Unit, Mexico

Reviewed by:

C. Brock Woodson,

University of Georgia, United States Olivia M. Cheriton,

Pacific Coastal and Marine Science Center, United States

*Correspondence:

Julio B. J. Harvey

jharvey@ucsc.edu

Specialty section:

This article was submitted to

Coastal Ocean Processes,

a section of the journal

Frontiers in Marine Science

Received: 02 January 2021

Accepted: 09 April 2021

Published: 14 May 2021

Citation:

Harvey JBJ, Ryan JP and Zhang Y (2021) Influences of Extreme Upwelling on a Coastal Retention Zone. Front. Mar. Sci. 8:648944. doi: 10.3389/fmars.2021.648944
Coastal retention zones occur in the lee of headlands and within bays of coastal upwelling environments. Because retention zones can concentrate and retain communities of coastal planktonic organisms that would otherwise be advected offshore by wind-driven transport, they are ecologically significant. While the consequences of these zones for plankton retention and recruitment have been examined, the degree to which they remain retentive under variable upwelling intensity is less well understood. This aspect of coastal plankton ecology was studied during 2012 in the retentive upwelling shadow of northern Monterey Bay, California. Environmental and biological data show that exceptionally strong upwelling can greatly diminish resident plankton populations in the upwelling shadow. Results indicate that wind-driven circulation, essential to primary productivity and the formation of retention zones, can surpass levels that allow accumulation and retention of plankton communities.

Keywords: coastal upwelling, zooplankton, RNA, autonomous underwater vehicle (AUV), California Current Ecosystem

\section{INTRODUCTION}

The prevalence of wind-driven offshore transport in coastal upwelling systems presents a challenge to marine plankton that must recruit to nearshore habitats. Retention of plankton communities can develop within zones where circulation slows or forms eddies, having major consequences for plankton ecology. Coastal retention zones represent biological hotspots, where upwelling circulation delivers chemical nutrients that fuel phytoplankton growth and support marine food webs (Dengler, 1985; Chekalyuk et al., 2012; Landry et al., 2012; Lara-Lopez et al., 2012; Samo et al., 2012). Where coastal headlands and bays are present (e.g., on the California central coast: northern Monterey Bay, Point Reyes, and Bodega Head), recirculating retention zones, termed "upwelling shadows," develop to leeward (Graham et al., 1992; Graham and Largier, 1997; Wing et al., 2003). Upwelling shadows accumulate invertebrate larvae (Roughan et al., 2005; Mace and Morgan, 2006b; Morgan et al., 2011) and are characterized by different assemblages of zooplankton, compared to adjacent water masses (Graham et al., 1992; Wing et al., 1998). Such retention zones are influential in determining larval transport and settlement (Roughan et al., 2005; Mace and Morgan, 2006a; Woodson et al., 2009). Tides and associated internal waves (tidal bores) also mediate invertebrate larval transport (Shanks, 1986; Pineda, 1991; Mace and Morgan, 2006b; Morgan et al., 2011), as do species-specific behavioral mechanisms (Pedrotti and Fenaux, 1992; Kingsford et al., 2002; Mace and Morgan, 2006a; Shanks, 2009; Morgan and Fisher, 2010; Morgan et al., 2012).

Monterey Bay, in the central California Current upwelling system, hosts a retentive upwelling shadow (Graham and Largier, 1997) that occupies much of the northern bay (Figure 1). 
Increased residence time in the Monterey Bay upwelling shadow (hereafter MBUS) causes relatively warm sea surface temperatures (Figure 1A) and enhanced vertical density stratification (Figure 1B). Retention also allows accumulation of phytoplankton populations, as evident in chlorophyll fluorescence patterns observed from both satellite remote sensing and in situ observations (Figures 1C,D). Zooplankton abundance and diversity are also enriched in the MBUS, particularly compared to recently upwelled waters that flow into the MBUS (Graham et al., 1992).

Ecological dynamics of the MBUS are intimately linked to the upwelling process. The primary supply of upwelled water to Monterey Bay originates at Point Año Nuevo (Figure 1A), a coastal headland north of the bay (Rosenfeld et al., 1994). Upwelling filaments from this upwelling center flow southward across the mouth of the bay and can bifurcate, with some upwelled water flowing offshore and some flowing into the bay (Rosenfeld et al., 1994). Previous studies have shown how the MBUS, and small-scale physical processes within it, can result in exceptionally dense aggregations of phytoplankton (Ryan et al., 2008, 2009, 2014b, 2017; Jessup et al., 2009) and zooplankton (Harvey et al., 2012; Zhang et al., 2012; Ryan et al., 2014a). Yet, upwelled water is typically impoverished of plankton, and large influxes of recently upwelled water into the MBUS have the potential to diminish the plankton community.

Fluctuations in planktonic biomass can be driven by various factors. Bottom-up mechanisms (e.g., upwelling-driven nutrient supply, physical forcing) are known to largely influence changes in planktonic communities of the California Current System (CCS, El-Sabaawi et al., 2012; Chenillat et al., 2013; Kahru et al., 2018; Lindegren et al., 2018). Upwelling-driven nutrient supply and resulting phytoplankton growth have major implications for higher trophic levels (Jahncke et al., 2008; Menge et al., 2009; Thompson et al., 2012). Physical forcing (e.g., upwelling-driven surface transport) can result in the advection of coastal plankton biomass offshore (Keister et al., 2009b; Bakun et al., 2015; Ruzicka et al., 2016). Additionally, interest in top-down mechanisms (e.g., predation) has increased considerably over the past 20 years (Baum and Worm, 2009). Although these studies primarily focus on higher trophic levels, top-down mechanisms have also been demonstrated for planktonic communities (Gaxiola-Castro et al., 2008; Landry et al., 2009; Fuchs and Franks, 2010). In the CCS, regulation of a system comprising phytoplankton, zooplankton and predatory fish is primarily mediated by bottomup mechanisms (Lindegren et al., 2018). Alternatively, this system can switch to a combination of top-down/bottom-up regulation during periods of weak upwelling, low nutrient concentrations, and diminished primary productivity (Lindegren et al., 2018). Yet, the latter study was conducted for the southern CCS, and similar results have not been shown for the northern CCS or for near-shore retention zones.

The strongest upwelling off central and northern California occurs during April through June (García-Reyes and Largier, 2012). This study took place during May-June 2012. To study the effects of upwelling circulation on the resident biomass of barnacles and copepods (Calanoida and Podoplea) in the MBUS, we conducted repeated sampling from an autonomous underwater vehicle (AUV) and a ship. Water samples were analyzed with zooplankton taxon-specific molecular probes to determine relative target ribonucleic acid (RNA) abundances, corresponding to invertebrate biomass (Goffredi et al., 2006; Jones et al., 2008; Harvey et al., 2013). These results were analyzed in the context of preceding and coincident environmental data, to examine the relationship between local zooplankton biomass and upwelling dynamics.

\section{METHODS}

\section{Contextual Environmental Data}

Satellite remote sensing data were used for two purposes. The first was to illustrate regional ecological patterns using longterm means of sea surface temperature (SST) from the Advanced Very High-Resolution Radiometer (AVHRR) sensors, and chlorophyll fluorescence line height (FLH) from the Moderate Resolution Imaging Spectroradiometer (MODIS) on the Aqua satellite (Figure 1). The spectral shape FLH algorithm captures intense phytoplankton blooms better than band-ratio chlorophyll algorithms (Ryan et al., 2009; Houskeeper and Kudela, 2019) and is thus better for climatological characterization. The second purpose was to illustrate variability during the study using synoptic (single-pass) AVHRR and MODIS images. The AVHRR image time-series was constrained to similar hours of the day (between 0 and 5) to minimize bias from diel changes in SST. Remotely sensed ocean surface currents from HF radar were used to examine circulation patterns. All remote sensing data were acquired through the National Oceanic and Atmospheric Administration (NOAA) Environmental Research Division's Data Access Program (ERDDAP) server ${ }^{1}$.

Observations from moorings were used to describe wind variability and oceanographic conditions. Wind measurements were from the National Data Buoy Center (NDBC) Station 46042 (Figure 1A); original data at $10-\mathrm{min}$ resolution were averaged in 6-h bins. Water column temperature and salinity were measured at mooring M1 (Figure 1A); original data at hourly resolution were averaged in 1-day bins. To evaluate the intensity of upwelling during the study period, we used upwelling indices (UI) modeled from atmospheric pressure fields (Schwing et al., 1996). Monthly UI at $36^{\circ} \mathrm{N}, 122^{\circ} \mathrm{W}$ for 2000 through 2019 , also acquired via ERDDAP, were analyzed to represent values of 2012 as anomalies (standard deviations relative to the long-term mean for each month).

Two data sets acquired by the Dorado AUV were used for different purposes. Key measurements from both data sets include temperature, salinity and depth from a SeaBird SBE 25 conductivity-temperature-depth (CTD) instrument, and chlorophyll fluorescence and optical backscatter from a HOBI Labs HS-2 instrument. The first data set is a 5-year (2003-2007) time-series of approximately monthly surveys along a transect that extended from mooring M1, at the central mouth of the bay, to the northeastern reaches of the MBUS (Ryan et al., 2008). For study context, mean conditions across the upwelling

\footnotetext{
${ }^{1}$ https://coastwatch.pfeg.noaa.gov/erddap/
} 


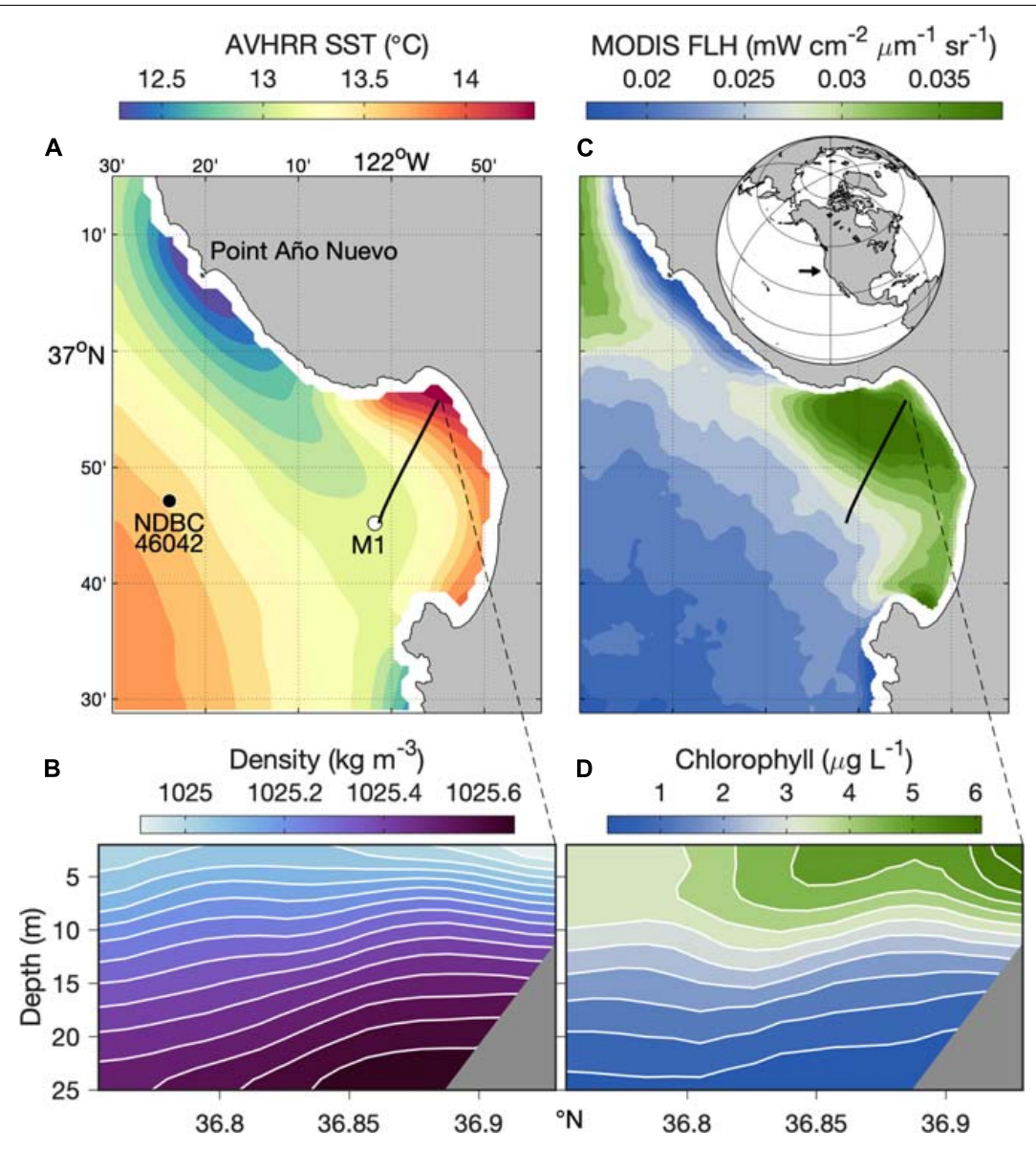

FIGURE 1 | Ecosystem patterns from long-term observations. Physical-(A) Sea Surface Temperature (SST) from the Advanced Very High-Resolution Radiometer (AVHRR) satellite sensors; the locations of mooring M1 (white dot), NDBC Station 46042 (black dot), and the Dorado AUV's historical transect (black line) are indicated. (B) Mean water density along the AUV transect (black line in panel A); isopycnals are indicated by white lines. Biological-(C) Normalized chlorophyll Fluorescence Line Height (FLH) from the Moderate Resolution Imaging Spectroradiometer (MODIS) satellite sensor; global location of the study region (inset, black arrow) is indicated. (D) Mean fluorometric chlorophyll concentration along the AUV transect (black line in panel C). Satellite data (A,C) represent 6-year (2003-2008) mean conditions for March through November. In situ data (B,D) represent 5-year (2003-2007) mean conditions from approximately monthly surveys along the AUV transect shown in the satellite data images during April through November. Latitudinal range along the AUV transect (X-axes) is indicated.

shadow and adjacent waters were computed from this time-series (Figure 1). The second AUV data set provided the synoptic sections and targeted water sample acquisition that are the focus of this study. A fixed transect was planned to cross the strongest gradients between the MBUS and adjacent upwelling filaments (Zhang et al., 2012). Each section, a $36 \mathrm{~km}$ transect along $36^{\circ} 54^{\prime} \mathrm{N}$ between $121^{\circ} 54^{\prime} \mathrm{W}$ and $122^{\circ} 18^{\prime} \mathrm{W}$ (Figure 2E), acquired $\sim 220$ yo-yo profiles between $2 \mathrm{~m}$ and $50 \mathrm{~m}$ depths (minimum $7.5 \mathrm{~m}$ above the seabed) in $\sim 9 \mathrm{~h}$. The average distance span of each profile was $160 \mathrm{~m}$. Each deployment consisted of two passes along the full transect, outbound followed by inbound. Sensor fouling precluded CTD data collection in one survey, on 6 June 2012.

The Dorado AUV was equipped with a Gulper sampling system which comprised ten $1.8 \mathrm{~L}$ syringe-like bottles that rapidly filled (1-2 s) to acquire discrete water samples (Bird et al., 2007). This system can achieve targeted water sampling according to onboard analyses that identify physical (water types) and optical (phytoplankton) features (Ryan et al., 2010; Zhang et al., 2010), and it has been used to elucidate various aspects of plankton ecology in the MBUS (Ryan et al., 2008, 2009, 2014b, 2017; Zhang et al., 2010, 2012; Harvey et al., 2012). Because zooplankton are discretely distributed in time and space, the AUV ran an adaptive detection and sampling algorithm to autonomously collect water samples in three distinct water types: within the chlorophyll enriched MBUS, within recently upwelled water, and within the front between these endmember water types (Zhang et al., 2012). This algorithm incorporates a peak-capture functionality for triggering sample collection within chlorophyll enriched patches of the MBUS (Zhang et al., 2010). The peak-capture algorithm enables identification and sampling of local chlorophyll maxima, effectively allowing water collection from areas of the water column where phytoplankton (and zooplankton grazers) are most abundant (Ryan et al., 2014a). For each survey three samples were set to be collected inshore of the upwelling front (i.e., in the MBUS retention zone), four within the upwelling front, and three in freshly upwelled waters. To minimize sample hold 
time in the AUV, all samples were collected during the inbound (second) transect. A total of 37 water samples were collected by the Dorado AUV across the MBUS and adjacent upwelling filament zone during 5 sampling days: 3 days while the MBUS was moderately disturbed by upwelling (30 May-1 June) and 2 days following strong disruption of the MBUS by upwelling circulation (6-7 June).

\section{Ship Water Sampling}

Water sampling from the R/V Fulmar was conducted during the AUV deployment period. This sampling employed a CTD rosette with $10 \mathrm{~L}$ Niskin bottles triggered at $10 \mathrm{~m}$ depth (except for one sample at $5 \mathrm{~m}$ depth) at fixed geographic points along the AUV transect, providing 13 additional samples. Because ship samples were part of a different research program and applied different RNA probes, they are examined independently of the AUV samples.

\section{Target Organism Detection}

Both AUV and ship collected water samples were vacuum filtered onto two $5 \mu \mathrm{m}$ Durapore filters (Millipore, Billerica, Massachusetts), placed in $2 \mathrm{~mL}$ cryogenic vials and frozen in liquid nitrogen. Samples were lysed, filtered and analyzed by Sandwich Hybridization Assay (SHA), as previously described (Goffredi et al., 2006; Jones et al., 2008; Harvey, 2012). SHA molecular probes detected RNA from common zooplankton targets (invertebrate larvae and various copepods) in water samples. SHA probes were previously developed and described elsewhere for barnacles (Goffredi et al., 2006; Jones et al., 2008) and various copepods (Harvey et al., 2012). RNA detection by SHA is a measure of target RNA molecules, a proxy for total biomass of zooplankton targets encountered in each sample (Harvey et al., 2013, 2017). Therefore, RNA detection reported here represents relative biomass for each target organism, but not total numbers of individuals.

Zooplankton detection frequency and biomass data were compared between water samples taken during contrasting periods of upwelling influence on the MBUS in May-June 2012. Comparisons employed the non-parametric Wilcoxon rank-sum test. Comparisons additionally employed the parametric $t$-test, if normality was indicated by the Shapiro-Wilk normality test.

\section{RESULTS}

\section{Environmental Variability}

Within the two decades spanning 2000 through 2019, peak upwelling in 2012 reached the 99th percentile of all monthly levels. During May 2012, the month during which we began sampling, the upwelling index was more than two standard deviations above the long-term mean for May (Figure 2A). Exceptionally strong upwelling persisted into June. The strong upwelling favorable (northwesterly) wind forcing during MayJune 2012 is evident in local wind measurements (Figure 2B). Water column observations at the mouth of Monterey Bay (mooring M1) show that the coldest and most saline conditions of 2012, indicative of coastal upwelling, coincided with our study period (Figures 2C,D). Thus, the potential for upwelling influence on the MBUS during our study was exceptional on both annual and decadal time scales.

Peak upwelling influence was evident at mooring M1 by 25 May, as surface outcropping of the coldest and most saline isopleths for the entire year (Figures 2C,D). Satellite observations show that this local outcropping at M1 was due to the transport of upwelled water originating along the coast north of Monterey Bay (Figure 2E), from the Point Año Nuevo upwelling center (Figure 1). The influence of this upwelling plume increased during late May and variably affected the MBUS during late May through early June (Figure 2E).

Synoptic in situ and remotely sensed observations clarify the progression of upwelling influence on the MBUS (Figure 3). As observed during 30 May through 1 June, recently upwelled water-relatively cold, saline, and chlorophyll impoverishedflowed along the outer periphery of the upwelling shadow, which was relatively warm, less saline, and chlorophyll rich (Figures 3A-C). At this time, hydrographic distinction of the MBUS was pronounced within the upper $20 \mathrm{~m}$ inshore of $\sim 122.2^{\circ} \mathrm{W}$ (Figures 3A-C). By 6-7 June distinction of the MBUS surface lens was greatly diminished as temperature decreased, salinity increased, and vertical stratification decreased (Figures 3E,F) compared to conditions during 30 May-June 1 (Figures $3 \mathrm{~A}-\mathrm{C}$ ). These changes, quantified by percentiles (Figure 3G), are consistent with the influx of recently upwelled water. Hydrographic changes were accompanied by reduced chlorophyll concentrations and extension of surface chlorophyll isopleths deeper into the water column within the bay, consistent with the diminished vertical stratification of temperature and salinity (compare Figures 3D-F with Figures 3A-C).

Remote sensing data confirm that these changes were associated with influx of recently upwelled water. Between the two sampling periods, average surface current velocity was dominated by cyclonic flow within and adjacent to Monterey Bay (Figure $3 \mathbf{H}$ ). Consistent with this flow pattern, a MODIS image from 7 June showed a plume of low-chlorophyll (blue) water flowing into the MBUS within the northward-flowing (eastern) portion of the cyclone, extending into our study area (Figure $3 \mathbf{H}$ ). This influx coincided with export of MBUS surface water along the boundary of the southward flowing filament of upwelled water, evident as the filament of high FLH (and green hue in the true-color image) extending NW-SE across the mouth of the bay (Figure 3H).

The true-color image also shows a filament of water with a white hue originating from the coastal upwelling center north of the bay (Figure $3 \mathbf{H}$, black arrow) and extending southeastward into the bay. Across the mouth of the bay this whitish filament was adjacent to the chlorophyll-rich filament exported from the MBUS, indicating transport by the same circulation. This feature was detected by the AUV. The maximum AUV optical backscatter signal during 6-7 June was within narrow bands in the upper $30 \mathrm{~m}$ of the water column (Figures 3D,E; highlighted by black contours overlaid in the chlorophyll panels). These backscattering maxima did not correspond to the chlorophyll fluorescence maxima, thus suggesting presence of non-phytoplankton particles. Because coastal upwelling couples 


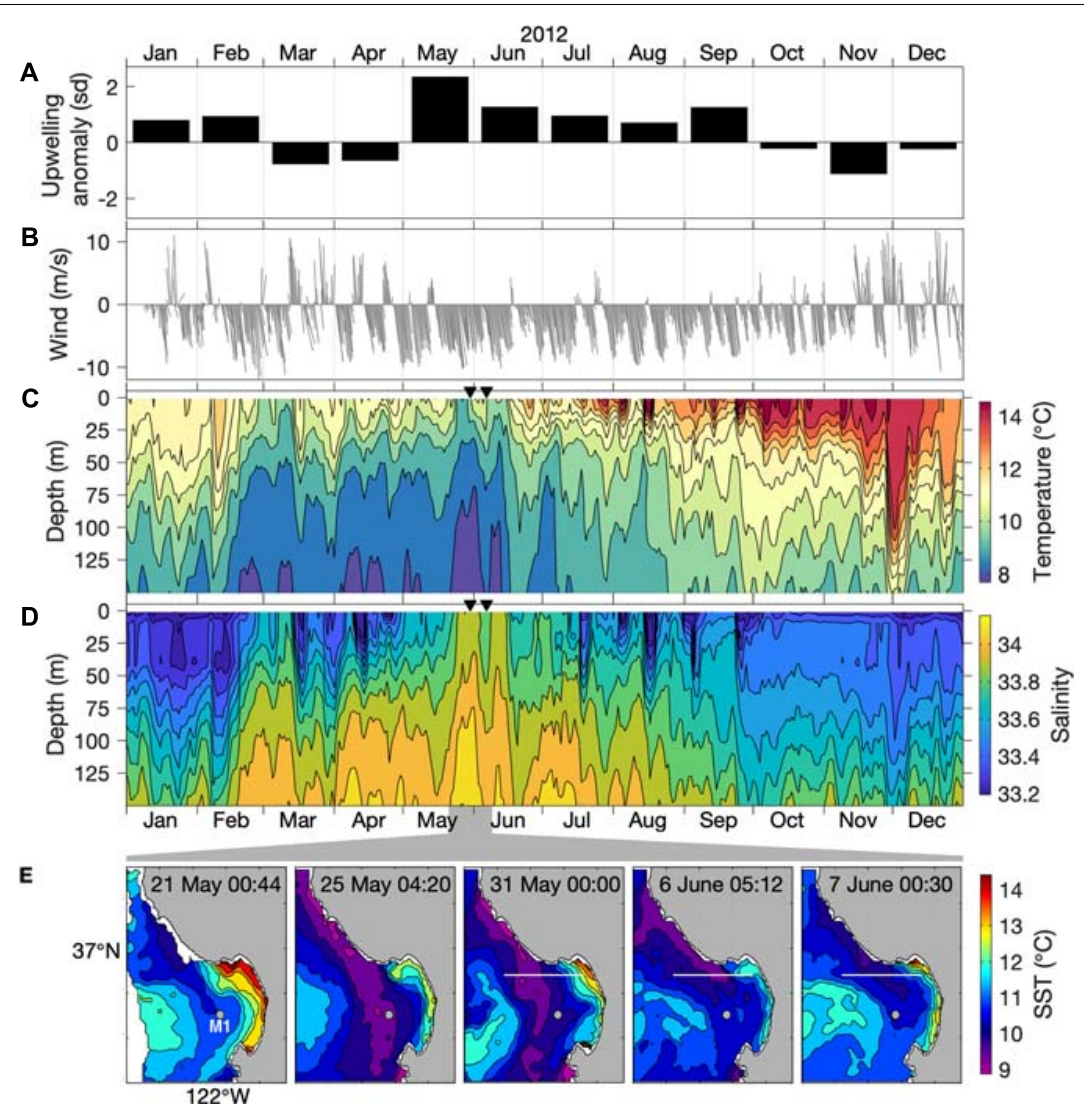

FIGURE 2 | Regional upwelling conditions. (A) Monthly anomaly of the upwelling index at $36^{\circ} \mathrm{N}, 122^{\circ} \mathrm{W}\left(\mathrm{m}^{3}\right.$ per second per $100 \mathrm{~m}$ of coastline) for 2012 , represented as standard deviations (sd) relative to a long-term (20-year) monthly climatology. (B) Wind speed from NDBC Station 46042 (location in Figure 1A). (C,D) Water-column temperature and salinity at the M1 mooring (location in Figure 1A). Triangles mark the start of two AUV sampling periods, 30 May (for 30 May through 1 June) and 6 June (for 6-7 June). (E) Sea surface temperature (SST) variation during 21 May-7 June 2012. Times are UTC. The location of mooring M1 (gray dot) is indicated. The $36^{\circ} 54^{\prime} \mathrm{N}$ AUV transect (white line) is indicated on days when AUV surveys were conducted (Figure 3).

the bottom boundary layer to the surface, and because upwelled water has very low phytoplankton abundance, we interpret that this optical feature was caused by particulate matter from the bottom boundary layer of the upwelling center that was transported into our study area.

\section{Biological Changes}

Coincident with the changes in hydrographic conditions and phytoplankton distributions induced by the upwelling influx (Figures 2, 3), zooplankton abundance, diversity, and detection frequency decreased (Figure 4). This shift occurred after the increase in upwelling flow into northern Monterey Bay. Prior to the upwelling influx (i.e., sampling period S1: 30 May-1 June), invertebrate zooplankton taxa were detected in $78 \%$ of AUV samples and $100 \%$ of ship samples, including barnacles, podoplean copepods and calanoid copepods. Following the upwelling influx (i.e., sampling period S2: 6-7 June), zooplankton detection occurred in only $40 \%$ of AUV samples and $83 \%$ of ship samples, and only calanoid copepods were detected in the AUV samples.

Although calanoid copepods were detected throughout the study, their RNA signals were significantly reduced during sampling period S2 compared to S1 (Figure 4). For the AUV samples, S1 and S2 medians of calanoid copepod RNA signals were 0.16 and 0 , respectively. The Wilcoxon rank-sum test $(n 1=27, n 2=10 ; p<0.01$; one-tailed $)$ indicated that the S1 median was greater and the difference is statistically significant. The Shapiro-Wilk test $(p<0.01)$ indicated that the null hypothesis of normal distribution should be rejected, thus precluding parametric analysis. For the ship samples, the S1 and S2 medians of calanoid copepod RNA signals were 0.38 and 0.13 , respectively. The Wilcoxon rank-sum test $(n 1=7, n 2=6 ; p<0.01$; one-tailed $)$ indicated that the S1 median was greater and the difference is statistically significant. The Shapiro-Wilk test $(p=0.63)$ indicated that the null hypothesis of normal distribution should be retained, thus allowing parametric analysis. Bartlett's test $(p=0.69)$ indicated that the null hypothesis of equal variances between S1 and S2 sample sets should not be rejected, so Student's $t$-test is appropriate. This $t$-test $(p<0.01)$ indicated that the S1 mean was greater than the S2 mean, and that the difference is statistically significant. Barnacles and podoplean copepods were not detected frequently enough for statistical analysis. 


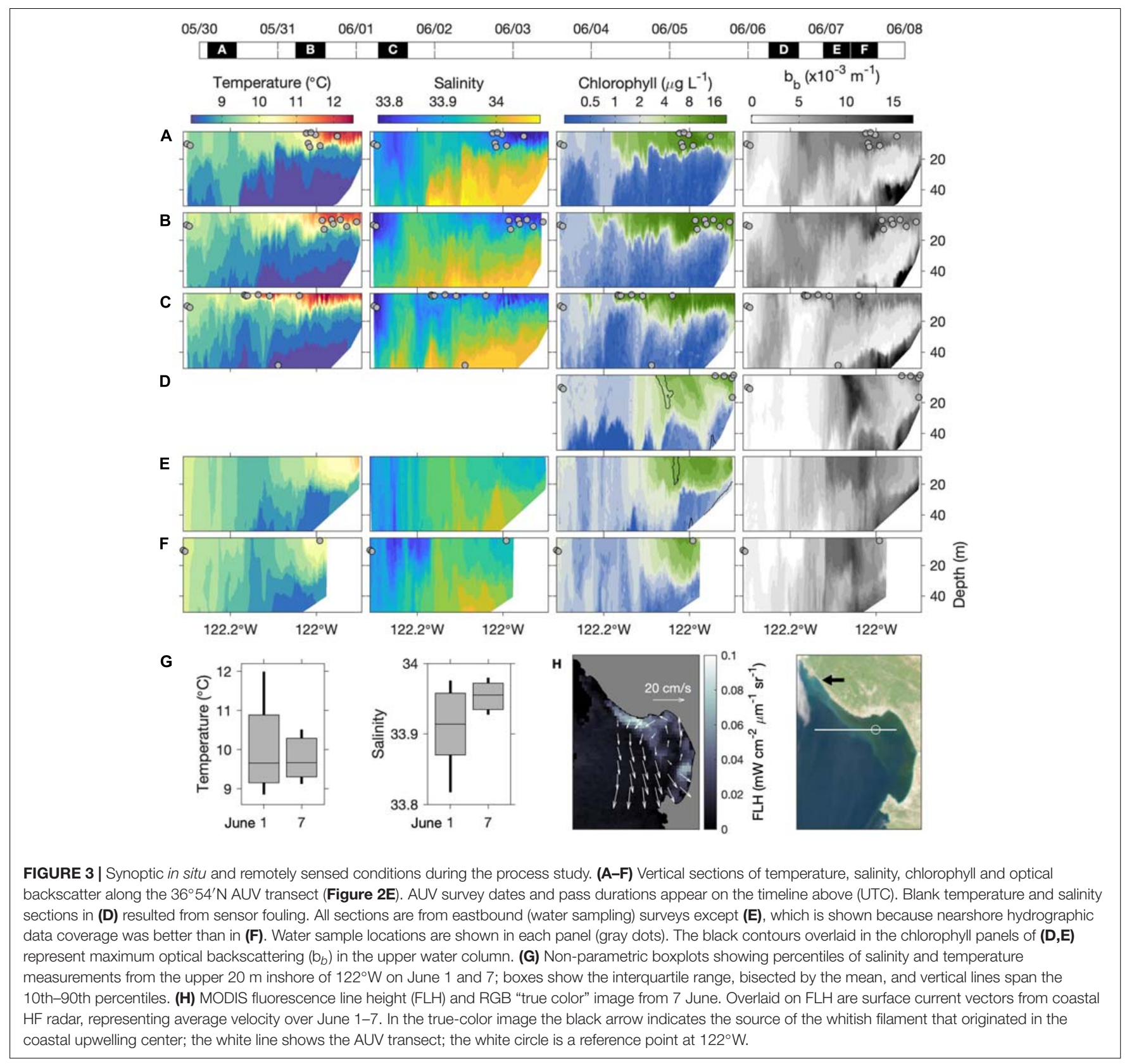

\section{DISCUSSION}

\section{Biological Distinction of the Upwelling Shadow}

Coastal upwelling brings nutrient-rich water to the surface and fuels phytoplankton growth that supports grazing zooplankton populations (González-Rodríguez et al., 2012; Ohman et al., 2012; Thompson et al., 2012). Through enhanced residence time, retentive upwelling shadows allow accumulation and maturation of diverse plankton communities (Roughgarden et al., 1991; Graham et al., 1992; Graham and Largier, 1997; Roughan et al., 2005; Morgan et al., 2011). Consistent with previous studies (Graham et al., 1992; Graham and Largier, 1997;
Ryan et al., 2008, 2009, 2014b; Woodson et al., 2009), this study demonstrates the biological distinction and significance of the MBUS. During May-June 2012, the MBUS exhibited local maxima in phytoplankton chlorophyll concentrations and zooplankton biomass and diversity. While causality of these biological patterns resulting from the upwelling shadow phenomenon is understood, the biological consequences of large variations in upwelling intensity are not.

\section{Influences of Upwelling Circulation on the Upwelling Shadow}

Variations in upwelling influence on the MBUS were resolved through multidisciplinary observations. Exceptionally strong and 

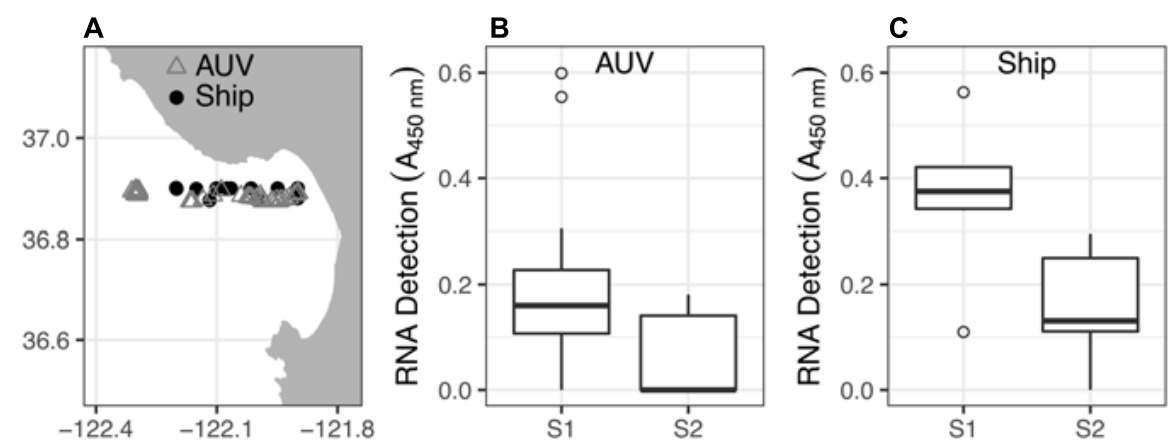

FIGURE 4 | Calanoid copepod RNA detection (biomass) from water samples collected by AUV and ship. (A) Map of all sample locations. (B) Non-parametric boxplots of sample calanoid copepod RNA signals from AUV water samples collected during sampling periods $S 1(n=27)$ and S2 $(n=10)$, corresponding to Figures 3A-F, respectively). (C) Non-parametric boxplots of RNA signals from ship water samples collected during S1 $(n=7)$ and S2 $(n=6)$.

persistent wind-driven upwelling near Point Año Nuevo and concomitant southward coastal flow progressively influenced Monterey Bay; first the outer bay during late May, then reaching the inner MBUS during early June. Remote sensing confirmed coupling of regional coastal upwelling flow to the MBUS, and in situ observations revealed the influences of this upwelling flow on hydrographic and optical properties within the bay. These processes disrupted the sheltering and retention of the MBUS (Graham and Largier, 1997), as indicated by two changes: (1) the shallow lens of relatively warm, less saline, chlorophyll-rich water became cooler, more saline, and less chlorophyll-rich, and (2) vertical stratification of temperature, salinity, and chlorophyll decreased. The influx of recently upwelled water-relatively cold, saline, chlorophyll impoverished, sediment enriched, and weakly stratifiedis consistent with the observed changes. This influx was accompanied by export of plankton-enriched waters from the MBUS, offshore and southward. A dominant cyclonic circulation within and outside the bay drove exchange between the MBUS and the upwelling plume and is likely the primary cause of diminished zooplankton abundance observed during the second sampling period.

Mixing of the two water types represents another possible factor in the reduction of zooplankton abundance. MBUS plankton populations that mix with recently upwelled, planktonimpoverished waters would be diluted. Strong lateral exchange of these contrasting water types is prone to mixing, as previously observed with high-resolution airborne remote sensing (Ryan et al., 2009), and mixing is indicated by the AUV data from this study. Persistence of a chlorophyll enriched surface layer throughout these major environmental changes implies that MBUS waters were not simply replaced by the influx of recently upwelled, chlorophyll-impoverished water, but rather that mixing of upwelled waters with resident MBUS waters occurred.

Although top-down mechanisms (e.g., planktivorous fish) are also known to reduce zooplankton biomass (Lindegren et al., 2018), the observed degree of calanoid copepod decrease (e.g., detection reduced from $78 \%$ to $40 \%$ of AUV samples) is likely primarily due to upwelling-driven advection from and dilution within the MBUS. Influx of recently upwelled, plankton-impoverished water would likely decrease foraging efficiency within the MBUS by decreasing plankton concentrations, making intensification of grazing an unlikely cause of diminished zooplankton biomass. Furthermore, although observations in the southern CCS indicate that similar ecosystems can switch from predominantly bottom-up to a combination of top-down and bottomup mechanisms (Lindegren et al., 2018), this only occurs during weak upwelling, with low nutrient concentrations. The latter conditions are converse to those observed during our study period.

\section{The Ecological Balance of Upwelling Shadows}

Overall, our observations support the conclusion that upwelling intensity affects the essential ecological functions of upwelling shadows as habitats for growth, accumulation, and maturation of plankton communities. Influx from coastal upwelling is essential to supplying the nutrients that fuel primary productivity. Variation in upwelling intensity undoubtedly mediates processes that shape upwelling shadow ecology. Moderate intermittent upwelling influx may support both productivity and retention, thereby allowing growth, accumulation, and time to develop abundant and diverse plankton communities. Although exceptionally strong upwelling may supply abundant nutrients for phytoplankton growth, the accompanying disruption of stability in upwelling shadow habitats may diminish retention and residence time, thereby diminishing the potential for accumulation of plankton across trophic levels. Similar decreases in abundance following spring upwelling have been noted for zooplankton and associated micronekton in Monterey bay, measured by acoustic backscatter (Urmy and Horne, 2016). Acoustically measured zooplankton biomass transport offshore has also been documented for the shelf area of the Heceta Bank off Newport, Oregon, during summer upwelling (Wu et al., 2014). More generally, upwelling filaments have been shown to advect zooplankton offshore and drive their distributions in the northern CCS (Keister et al., 2009a,b). 
The phenology of upwelling has proven critical for understanding the consequences of variation in productivity for local, near-shore populations of marine organisms. For example, late initiation of upwelling can have dire consequences for marine mammals and seabirds (Melin et al., 2010; Black et al., 2014). Upwelling strength is commonly considered a covariant of ecosystem productivity. While this is true for integrated primary productivity (García-Reyes and Largier, 2012; González-Gil et al., 2015; Wang et al., 2015), our results suggest that upwelling strength beyond a certain intensity may diminish the ecological richness of retention zones, by displacing or diluting resident plankton populations. Future studies of how coastal physical processes affect nearshore ecology in coastal upwelling ecosystems may benefit from consideration of the potentially diminishing effects of anomalously strong upwelling on retention zones.

\section{DATA AVAILABILITY STATEMENT}

The original contributions presented in the study are included in the article. Further inquiries can be directed to the corresponding author.

\section{REFERENCES}

Bakun, A., Black, B. A., Bograd, S. J., García-Reyes, M., Miller, A. J., Rykaczewski, R. R., et al. (2015). Anticipated effects of climate change on coastal upwelling ecosystems. Curr. Clim. Change Rep. 1, 85-93. doi: 10.1007/s40641-0150008-4

Baum, J. K., and Worm, B. (2009). Cascading top-down effects of changing oceanic predator abundances. J. Anim. Ecol. 78, 699-714. doi: 10.1111/j.1365-2656. 2009.01531.x

Bird, L. E., Sherman, A., and Ryan, J. (2007). "Development of an active, large volume, discrete seawater sampler for autonomous underwater vehicles," in Proceedings of the Oceans, (Vancouver, BC: MTS/IEEE), 1-5.

Black, B. A., Sydeman, W. J., Frank, D. C., Griffin, D., Stahle, D. W., GarcíaReyes, M., et al. (2014). Six centuries of variability and extremes in a coupled marine-terrestrial ecosystem. Science 345, 1498-1502. doi: 10.1126/science. 1253209

Chekalyuk, A. M., Landry, M. R., Goericke, R., Taylor, A. G., and Hafez, M. A. (2012). Laser fluorescence analysis of phytoplankton across a frontal zone in the California Current ecosystem. J. Plankton Res. 34, 761-777. doi: 10.1093/ plankt/fbs034

Chenillat, F., Rivière, P., Capet, X., Franks, P. J. S., and Blanke, B. (2013). California coastal upwelling onset variability: cross-shore and bottom-up propagation in the planktonic ecosystem. PLoS One 8:e62281. doi: 10.1371/journal.pone. 0062281

Dengler, A. T. (1985). Relationship between physical and biological processes at an upwelling front off Peru, $15^{\circ}$ S. Deep Sea Res. Part. A 32, 1301-1315. doi: 10.1016/0198-0149(85)90050-0

El-Sabaawi, R. W., Trudel, M., Mackas, D. L., Dower, J. F., and Mazumder, A. (2012). Interannual variability in bottom-up processes in the upstream range of the California Current system: an isotopic approach. Prog. Oceanogr. 106, 16-27. doi: 10.1016/j.pocean.2012.06.004

Fuchs, H. L., and Franks, P. J. S. (2010). Plankton community properties determined by nutrients and size-selective feeding. Mar. Ecol. Prog. Ser. 413, 1-15. doi: $10.3354 /$ meps 08716

García-Reyes, M., and Largier, J. L. (2012). Seasonality of coastal upwelling off central and northern California: new insights, including temporal and spatial variability. J. Geophys. Res. Oceans 117:C03028. doi: 10.1016/j.pocean.2011.07. 019

\section{AUTHOR CONTRIBUTIONS}

$\mathrm{JH}$, JR, and YZ contributed to conception, design, and implementation of the study. JH conducted all water sample processing and RNA analysis. JR conducted the environmental analysis from AUV, mooring, satellite, HF radar, and model data sources. YZ led development of the AUV sampling algorithm. All authors co-wrote the manuscript and approved the submitted version.

\section{FUNDING}

This research was conducted at the Monterey Bay Aquarium Research Institute and supported by the David and Lucile Packard Foundation.

\section{ACKNOWLEDGMENTS}

We thank the Dorado AUV team and the R/V Zephyr crew for AUV operations.

Gaxiola-Castro, G., Durazo, R., Lavaniegos, B., De La Cruz-Orozco, M. E., MillánNúñez, E., Soto-Mardones, L., et al. (2008). Pelagic ecosystem response to interannual variability off Baja California. Cienc. Mar. 34, 263-270.

Goffredi, S. K., Jones, W. J., Scholin, C. A., Marin, R., and Vrijenhoek, R. C. (2006). Molecular detection of marine invertebrate larvae. Mar. Biotechnol. 8, 149-160. doi: 10.1007/s10126-005-5016-2

González-Gil, R., Taboada, F. G., Höfer, J., and Anadón, R. (2015). Winter mixing and coastal upwelling drive long-term changes in zooplankton in the Bay of Biscay (1993-2010). J. Plankton Res. 37, 337-351. doi: 10.1093/plankt/fbv001

González-Rodríguez, E., Trasviña-Castro, A., Gaxiola-Castro, G., Zamudio, L., and Cervantes-Duarte, R. (2012). Net primary productivity, upwelling and coastal currents in the Gulf of Ulloa. Baja California, México. Ocean Sci. 8, 703-711. doi: 10.5194/os-8-703-2012

Graham, W. M., Field, J. G., and Potts, D. C. (1992). Persistent "upwelling shadows" and their influence on zooplankton distributions. Mar. Biol. 114, 561-570. doi: 10.1007/bf00357253

Graham, W. M., and Largier, J. L. (1997). Upwelling shadows as nearshore retention sites: the example of northern Monterey Bay. Cont. Shelf. Res. 17, 509-532. doi: 10.1016/s0278-4343(96)00045-3

Harvey, J. B. J. (2012). “A 96-well plate format for detection of marine zooplankton with the sandwich hybridization assay," in Developmental Biology of the Sea Urchin and Other Marine Invertebrates, Methods in Molecular Biology, eds D. J. Carroll and S. A. Stricker (New York, NY: Springer), 263-276. doi: 10.1007/9781-62703-974-1_18

Harvey, J. B. J., Djunaedi, A. F., and Vrijenhoek, R. C. (2013). Validation of a sandwich hybridization assay for marine copepod detection. J. Exp. Mar. Biol. Ecol. 446, 306-310. doi: 10.1016/j.jembe.2013.06.005

Harvey, J. B. J., Johnson, S. B., Fisher, J. L., Peterson, W. T., and Vrijenhoek, R. C. (2017). Comparison of morphological and next generation DNA sequencing methods for assessing zooplankton assemblages. J. Exp. Mar. Biol. Ecol. 487, 113-126. doi: 10.1016/j.jembe.2016.12.002

Harvey, J. B. J., Ryan, J. P., Marin, R., Preston, C. M., Alvarado, N., Scholin, C. A., et al. (2012). Robotic sampling, in situ monitoring and molecular detection of marine zooplankton. J. Exp. Mar. Biol. Ecol. 413, 60-70. doi: 10.1016/j.jembe. 2011.11.022

Houskeeper, H. F., and Kudela, R. M. (2019). Ocean color quality control masks contain the high phytoplankton fraction of coastal ocean observations. Remote Sens. 11:2167. doi: 10.3390/rs11182167 
Jahncke, J., Saenz, B. L., Abraham, C. L., Rintoul, C., Bradley, R. W., and Sydeman, W. J. (2008). Ecosystem responses to short-term climate variability in the Gulf of the Farallones. California. Prog. Oceanogr. 77, 182-193. doi: 10.1016/j. pocean.2008.03.010

Jessup, D. A., Miller, M. A., Ryan, J. P., Nevins, H. M., Kerkering, H. A., Mekebri, A., et al. (2009). Mass stranding of marine birds caused by a surfactantproducing red tide. PLoS One 4:e4550. doi: 10.1371/journal.pone.0004550

Jones, W. J., Preston, C. M., Marin, R. III, Scholin, C. A., and Vrijenhoek, R. C. (2008). A robotic molecular method for in situ detection of marine invertebrate larvae. Mol. Ecol. Resour. 8, 540-550. doi: 10.1111/j.1471-8286.2007.02021.x

Kahru, M., Jacox, M. G., and Ohman, M. D. (2018). CCE1: decrease in the frequency of oceanic fronts and surface chlorophyll concentration in the California Current System during the 2014-2016 Northeast Pacific warm anomalies. Deep Sea Res. Part. I 140, 4-13. doi: 10.1016/j.dsr.2018.04.007

Keister, J. E., Cowles, T. J., Peterson, W. T., and Morgan, C. A. (2009a). Do upwelling filaments result in predictable biological distributions in coastal upwelling ecosystems? Prog. Oceanogr. 83, 303-313. doi: 10.1016/j.pocean. 2009.07.042

Keister, J. E., Peterson, W. T., and Pierce, S. D. (2009b). Zooplankton distribution and cross-shelf transfer of carbon in an area of complex mesoscale circulation in the northern California Current. Deep Sea Res. Part. I 56, 212-231. doi: 10.1016/j.dsr.2008.09.004

Kingsford, M. J., Leis, J. M., Shanks, A., Lindeman, K. C., Morgan, S. G., and Pineda, J. (2002). Sensory environments, larval abilities and local self-recruitment. Bull. Mar. Sci. 70, 309-340.

Landry, M. R., Ohman, M. D., Goericke, R., Stukel, M. R., Barbeau, K. A., Bundy, R., et al. (2012). Pelagic community responses to a deep-water front in the California current ecosystem: overview of the A-Front Study. J. Plankton Res. 34, 739-748. doi: 10.1093/plankt/fbs025

Landry, M. R., Ohman, M. D., Goericke, R., Stukel, M. R., and Tsyrklevich, K. (2009). Lagrangian studies of phytoplankton growth and grazing relationships in a coastal upwelling ecosystem off Southern California. Prog. Oceanogr. 83, 208-216. doi: 10.1016/j.pocean.2009.07.026

Lara-Lopez, A. L., Davison, P., and Koslow, J. A. (2012). Abundance and community composition of micronekton across a front off Southern California. J. Plankton Res. 34, 828-848. doi: 10.1093/plankt/fbs016

Lindegren, M., Checkley, D. M. Jr., Koslow, J. A., Goericke, R., and Ohman, M. D. (2018). Climate-mediated changes in marine ecosystem regulation during El Niño. Glob. Chang. Biol. 24, 796-809.

Mace, A. J., and Morgan, S. G. (2006a). Biological and physical coupling in the lee of a small headland: contrasting transport mechanisms for crab larvae in an upwelling region. Mar. Ecol. Prog. Ser. 324, 185-196. doi: 10.3354/meps324185

Mace, A. J., and Morgan, S. G. (2006b). Larval accumulation in the lee of a small headland: implications for the design of marine reserves. Mar. Ecol. Prog. Ser. 318, 19-29. doi: 10.3354/meps318019

Melin, S., Orr, A., Harris, J., Laake, J., DeLong, R., Gulland, F., et al. (2010). Unprecedented mortality of California sea lion pups associated with anomalous oceanographic conditions along the central California coast in 2009. Cal. Coop. Ocean. Fish. 51, 182-194.

Menge, B. A., Chan, F., Nielsen, K. J., Lorenzo, E. D., and Lubchenco, J. (2009). Climatic variation alters supply-side ecology: impact of climate patterns on phytoplankton and mussel recruitment. Ecol. Monogr. 79, 379-395. doi: 10. 1890/08-2086.1

Morgan, S., and Fisher, J. (2010). Larval behavior regulates nearshore retention and offshore migration in an upwelling shadow and along the open coast. Mar. Ecol. Prog. Ser. 404, 109-126. doi: 10.3354/meps08476

Morgan, S. G., Fisher, J. L., and Largier, J. L. (2011). Larval retention, entrainment, and accumulation in the lee of a small headland: recruitment hotspots along windy coasts. Limnol. Oceanogr. 56, 161-178. doi: 10.4319/lo.2011.56.1. 0161

Morgan, S. G., Fisher, J. L., McAfee, S. T., Largier, J. L., and Halle, C. M. (2012). Limited recruitment during relaxation events: larval advection and behavior in an upwelling system. Limnol. Oceanogr. 57, 457-470. doi: 10.4319/lo.2012.57. 2.0457

Ohman, M. D., Powell, J. R., Picheral, M., and Jensen, D. W. (2012). Mesozooplankton and particulate matter responses to a deep-water frontal system in the southern California Current System. J. Plankton Res. 34, 815-827. doi: $10.1093 /$ plankt/fbs028
Pedrotti, M. L., and Fenaux, L. (1992). Dispersal of echinoderm larvae in a geographical area marked by upwelling (Ligurian Sea, NW Mediterranean). Mar. Ecol. Prog. Ser. 87, 217-227. doi: 10.3354/meps 087217

Pineda, J. (1991). Predictable upwelling and the shoreward transport of planktonic larvae by internal tidal bores. Science 253, 548-549. doi: 10.1126/science.253. 5019.548

Rosenfeld, L. K., Schwing, F. B., Garfield, N., and Tracy, D. E. (1994). Bifurcated flow from an upwelling center: a cold water source for Monterey Bay. Cont. Shelf. Res. 14, 931-964. doi: 10.1016/0278-4343(94)90058-2

Roughan, M., Mace, A. J., Largier, J. L., Morgan, S. G., Fisher, J. L., and Carter, M. L. (2005). Subsurface recirculation and larval retention in the lee of a small headland: a variation on the upwelling shadow theme. J. Geophys. Res. Oceans 110:C10027.

Roughgarden, J., Pennington, J. T., Stoner, D. S., Alexander, S., and Miller, K. (1991). Collisions of upwelling fronts with the intertidal zone: the cause of recruitment pulses in barnacle populations of central California. Acta Oecol. 12, 35-51.

Ruzicka, J. J., Brink, K. H., Gifford, D. J., and Bahr, F. (2016). A physically coupled end-to-end model platform for coastal ecosystems: simulating the effects of climate change and changing upwelling characteristics on the Northern California Current ecosystem. Ecol. Model. 331, 86-99. doi: 10.1016/ j.ecolmodel.2016.01.018

Ryan, J. P., Fischer, A. M., Kudela, R. M., Gower, J. F. R., King, S. A., Marin, R., et al. (2009). Influences of upwelling and downwelling winds on red tide bloom dynamics in Monterey Bay. California. Cont. Shelf. Res. 29, 785-795. doi: 10.1016/j.csr.2008.11.006

Ryan, J. P., Gower, J. F. R., King, S. A., Bissett, W. P., Fischer, A. M., Kudela, R. M., et al. (2008). A coastal ocean extreme bloom incubator. Geophys. Res. Lett. 35:L12602.

Ryan, J. P., Harvey, J. B. J., Zhang, Y., and Woodson, C. B. (2014a). Distributions of invertebrate larvae and phytoplankton in a coastal upwelling system retention zone and peripheral front. J. Exp. Mar. Biol. Ecol. 459, 51-60. doi: 10.1016/j. jembe.2014.05.017

Ryan, J. P., McManus, M. A., Kudela, R. M., Lara Artigas, M., Bellingham, J. G., Chavez, F. P., et al. (2014b). Boundary influences on HAB phytoplankton ecology in a stratification-enhanced upwelling shadow. Deep Sea Res. Part. II 101, 63-79. doi: 10.1016/j.dsr2.2013.01.017

Ryan, J. P., Johnson, S. B., Sherman, A., Rajan, K., Py, F., Thomas, H., et al. (2010). Mobile autonomous process sampling within coastal ocean observing systems. Limnol. Oceanogr. Meth. 8, 394-402. doi: 10.4319/lom.2010. 8.394

Ryan, J. P., Kudela, R. M., Birch, J. M., Blum, M., Bowers, H. A., Chavez, F. P., et al. (2017). Causality of an extreme harmful algal bloom in Monterey Bay, California, during the 2014-2016 Northeast Pacific warm anomaly. Geophys. Res. Lett. 44, 5571-5579. doi: 10.1002/2017gl072637

Samo, T. J., Pedler, B. E., Ball, G. I., Pasulka, A. L., Taylor, A. G., Aluwihare, L. I., et al. (2012). Microbial distribution and activity across a water mass frontal zone in the California Current ecosystem. J. Plankton Res. 34, 802-814. doi: 10.1093/plankt/fbs048

Schwing, F. B., O'Farrell, M., Steger, J., and Baltz, K. (1996). Coastal upwelling indices, west coast of North America 1946-1995. Washington, DC: NOAA. NOAA Technical Memorandum NMFS-SWFSC-231.

Shanks, A. (1986). Tidal periodicity in the daily settlement of intertidal barnacle larvae and an hypothesized mechanism for the cross-shelf transport of cyprids. Biol. Bull. 170, 429-440. doi: 10.2307/1541852

Shanks, A. (2009). Pelagic larval duration and dispersal distance revisited. Biol. Bull. 216, 373-385. doi: 10.1086/bblv216n3p373

Thompson, S. A., Sydeman, W. J., Santora, J. A., Black, B. A., Suryan, R. M., Calambokidis, J., et al. (2012). Linking predators to seasonality of upwelling: using food web indicators and path analysis to infer trophic connections. Prog. Oceanogr. 101, 106-120. doi: 10.1016/j.pocean.2012.02.001

Urmy, S. S., and Horne, J. K. (2016). Multi-scale responses of scattering layers to environmental variability in Monterey Bay, California. Deep Sea Res. Part. I 113, 22-32. doi: 10.1016/j.dsr.2016.04.004

Wang, D., Gouhier, T. C., Menge, B. A., and Ganguly, A. R. (2015). Intensification and spatial homogenization of coastal upwelling under climate change. Nature 518, 390-394. doi: 10.1038/nature14235 
Wing, S. R., Botsford, L. W., Morgan, L. E., Diehl, J. M., and Lundquist, C. J. (2003). Inter-annual variability in larval supply to populations of three invertebrate taxa in the Northern California current. Estuar. Coast. Shelf. Sci. 57, 859-872. doi: 10.1016/s0272-7714(02)00416-x

Wing, S. R., Botsford, L. W., Ralston, S. V., and Largier, J. L. (1998). Meroplanktonic distribution and circulation in a coastal retention zone of the Northern California upwelling system. Limnol. Oceanogr. 43, 1710-1721. doi: 10.4319/ lo.1998.43.7.1710

Woodson, C. B., Washburn, L., Barth, J. A., Hoover, D. J., Kirincich, A. R., McManus, M. A., et al. (2009). Northern Monterey Bay upwelling shadow front: observations of a coastally and surface-trapped buoyant plume. J. Geophys. Res. Oceans 114:C12013.

Wu, D., Zhou, M., Pierce, S. D., Barth, J. A., and Cowles, T. (2014). Zooplankton distribution and transport in the California current off oregon. Mar. Ecol. Prog. Ser. 508, 87-103. doi: 10.3354/meps10835

Zhang, Y., McEwen, R., Ryan, J., and Bellingham, J. (2010). Design and tests of an adaptive triggering method for capturing peak samples in a thin phytoplankton layer by an autonomous underwater vehicle. IEEE J. Oceanic Eng. 35, 785-796. doi: 10.1109/joe.2010.2081031

Zhang, Y., Ryan, J., Bellingham, J., Harvey, J., and McEwen, R. (2012). Autonomous detection and sampling of water types and fronts in a coastal upwelling system by autonomous underwater vehicle. Limnol. Oceanogr. Meth. 10, 934-951. doi: 10.4319/lom.2012.10.934

Conflict of Interest: The authors declare that the research was conducted in the absence of any commercial or financial relationships that could be construed as a potential conflict of interest.

Copyright (C) 2021 Harvey, Ryan and Zhang. This is an open-access article distributed under the terms of the Creative Commons Attribution License (CC BY). The use, distribution or reproduction in other forums is permitted, provided the original author(s) and the copyright owner(s) are credited and that the original publication in this journal is cited, in accordance with accepted academic practice. No use, distribution or reproduction is permitted which does not comply with these terms. 